\title{
Inflammatory Cytokines Induce Expression of Chemokines by Human Retinal Cells: Role in Chemokine Receptor Mediated Age-related Macular Degeneration
}

\author{
Chandrasekharam N. Nagineni ${ }^{1, *}$, Vijay K. Kommineni ${ }^{1}$, Nader Ganjbaksh ${ }^{1}$, Krishnasai K. \\ Nagineni $^{2}$, John J. Hooks ${ }^{1}$, Barbara Detrick ${ }^{3, *}$ \\ ${ }^{1}$ Laboratory of Immunology, National Eye Institute, National Institutes of Health, Bethesda, MD 20892 , \\ USA \\ ${ }^{2}$ School of Public Policy, University of Maryland, College Park, MD 20742, USA \\ ${ }^{3}$ Department of Pathology, Johns Hopkins University, School of Medicine, Baltimore, MD 21205, USA
}

[Received November 14, 2014; Revised March 20, 2015; Accepted March 23, 2015]

\begin{abstract}
Chemokine reeptor-3 (CCR-3) was shown to be associated with choroidal neovascularization (CNV) in age-related macular degeneration (AMD). AMD is a vision threatening retinal disease that affects the aging population world-wide. Retinal pigment epithelium and choroid in the posterior part of the retina are the key tissues targeted in the pathogenesis of CNV in AMD. We used human retinal pigment epithelial (HRPE) and choroidal fibroblast (HCHF) cells, prepared from aged adult human donor eyes, to evaluate the expression of major CCR-3 ligands, CCL-5, CCL -7, CCL-11,CCL-24 and CCL-26. Microarray analysis of gene expression in HRPE cells treated with inflammatory cytokine mix $($ ICM $=$ IFN- $\gamma+$ TNF- $\alpha+I L-1 \beta)$ revealed 75 and 23-fold increase in CCL-5 and CCL-7 respectively, but not CCL-11, CCL-24 and CCL-26. Chemokine secretion studies of the production of CCL5 and CCL7 by HRPE corroborated with the gene expression analysis data. When the HRPE cells were treated with either individual cytokines or the ICM, both CCL-5 and CCL-7 were produced in a dose dependent manner. Similar to the gene expression data, the ICM did not enhance HRPE production of CCL-11, CCL-24 and CCL-26. CCL-11 and CCL-26 were increased with IL-4 treatment and this HRPE production was augmented in the presence of TNF- $\alpha$ and IL1 $\beta$. When HCHF cells were treated with either individual cytokines or the ICM, both CCL-5 and CCL-7 were produced in a dose dependent fashion. IL-4 induced low levels of CCL-11 and CCL-26 in HCHF and this production was significantly enhanced by TNF- $\alpha$. Under these conditions, neither HRPE nor HCHF were demonstrated to produce CCL-24. These data demonstrate that chronic inflammation triggers CCL-5 and CCL-7 release by HRPE and HCHF and the subsequent interactions with CCR3 may participate in pathologic processes in AMD.
\end{abstract}

Key words: Age-related macular degeneration, Retinal pigment epithelium, Retina, Inflammation, Choroidal neovascularization, Chemokines, CCR3

Age-related macular degeneration (AMD) affects aging population world-wide with a progressive loss of central vision due to the degeneration of macular region in the retina [1-3]. AMD is classified into two types, geographic atrophy (dry) characterized by accumulation of drusen and degeneration of retinal pigment epithelium (RPE), and exudative form (wet) in which new blood vessels grow from choroidal capillaries and invade into the retina through breaks in Bruch's membrane and RPE [4-6]. Choroidal neovascularization (CNV) is the hallmark of wet form of AMD that require therapeutic intervention to prevent loss of vision [5-8]. Clinicopathological, epidemiological and genome-wide association studies indicated several causative factors for AMD [7-10]. There is strong evidence to support inflammation as one of the pathogenic mechanisms involved in the development of 
AMD [11-16]. In addition, the involvement of inflammatory molecules produced by infiltrating leukocytes has been shown to play a key role in the pathophysiological processes of CNV in AMD [9-12].

RPE and choroidal tissues, located behind the neuroretina, are the primary targets associated with $\mathrm{CNV}$ and AMD [4, 8, 10, 12, 17]. The RPE with its highly organized basement membrane, known as Bruch's membrane, is essential for normal functioning of the retina $[18,19]$. The RPE acts as a blood retinal barrier and regulates, a) transport of fluids, nutrients and wastes from the choroid to the retina and vice versa $b$ ) engulfment and digestion digest photoreceptor outer segments c) secretion of extracellular matrix materials for retinal adhesion and maintenance of the integrity of Bruch's membrane [18, 19]. RPE secretes a number of growth factors, cytokines and chemokines and participates in the regulation of physiology and patho-biology of neuroretina and choroid [20-28].

The presence of lymphocytes, macrophages, complement factors $\mathrm{C} 3 \mathrm{a}$ and $\mathrm{C} 5$, matrix-metalloproteases and other inflammatory molecules in CNV membranes suggests a strong association between inflammatory reactions and AMD [8-12]. An association between genetic polymorphisms in complement factor $\mathrm{H}$ and AMD patients also underscore a role of immune system in AMD pathogenesis [7, 8]. The trafficking of inflammatory cells to the RPE and choroidal compartments may produce a number of cytokines and chemokines that would further activate resident RPE and choroidal cells to initiate a cascade of events that trigger the pathogenic processes. Recently, we reported that inflammatory cytokines, IFN- $\gamma$, TNF- $\alpha$ and IL- 1 enhance the secretion of vascular endothelial growth factors (VEGF-A and VEGF-C) by human RPE and choroidal fibroblast cells [21, 27, 28]. These results suggest a direct link among inflammation, VEGF secretion and neovascularization.

Chemokines, chemotactic cytokines, are small diffusible protein molecules $(8-14 \mathrm{kDa})$ secreted by various cell types in response to inflammatory, infectious and autoimmune disease signals [29-32]. Chemokines are classified into two major groups, $\mathrm{C}-\mathrm{C}$ or $\mathrm{C}-\mathrm{X}-\mathrm{C}$, based on number of amino acids present between first two conserved N-terminal cysteines [29, 32]. The biological effects of chemokines are mediated through seven transmembrane $\mathrm{G}$ protein coupled receptors (GPCR) by activating a number of membrane phospholipases and other signaling molecules $[31,32]$. The ligands (L) for C$\mathrm{C}$ and $\mathrm{C}-\mathrm{X}-\mathrm{C}$ chemokines are named as CCL and CXCL while their receptors (R) are termed as CCR and CXCR respectively [30-32]. Multiple chemokine ligands can bind to the same receptor belonging to $\mathrm{C}-\mathrm{C}$ or $\mathrm{C}-\mathrm{X}-\mathrm{C}$ family, suggesting over lapping and redundant specificities. For example, CCR3 can bind multiple ligands CCL-3,-5, -7, -11, -13, -15, -24, -26 and -28 ; CCR5 can bind CCL-3, -4, -5, -7, -8,-14and -16 with varying affinities [31, 32]. Most CXC ligands are targeted to neutrophils while $\mathrm{CC}$ ligands are targeted to monocyte/ macrophages. Both $\mathrm{CC}$ and $\mathrm{CXC}$ ligands are targeted to $\mathrm{T}$ and B lymphocytes [31, 32]. Chemokines play critical roles in the inflammatory and infectious diseases by regulating neutrophil, macrophage and lymphocyte trafficking to the pathological sites [29-32].

Chemokine receptor-3 (CCR-3) (CD193) was shown to play a critical role in CNV in AMD [33-35]. CCR-3 was detected on choroidal endothelial cells in CNV in untreated AMD patients [33,34]. Generally it is known that CCR-3 is expressed predominantly in leukocytes (eosinophils, basophils, mast cells, T lymphocytes) that are primarily associated with allergic inflammation disorders in lungs, conjunctiva and other tissues [36-39]. Physiologically active chemokine ligands for CCR-3 include eotaxins (CCL-11, 24, 26), RANTES (CCL-5) and MCP-3 (CCL-7), in addition to other chemokine ligands $[31,32]$. Eotaxins act exclusively through CCR-3, while CCL-5 mediates its action through CCR-1, -3, -5 and CCL-7 through CCR-1, -2, -3 [31, 32]. While expression of CCR-3 on CNV endothelial cells in AMD was previously demonstrated [33], the sources of chemokine ligands that interact with CCR-3 receptors are largely unknown and remain to be investigated.

In this study we used human retinal pigment epithelial and choroidal fibroblast cell cultures prepared from adult donor eyes to evaluate the expression and production of CCR-3 ligands CCL-5, -7, -11, -24, and 26. Here, we report that inflammatory cytokines IFN- $\gamma$, TNF- $\alpha$, IL- $1 \beta$ and IL-4 induce CC ligands, predominantly CCL-5 and CCL-7.

\section{MATERIALS AND METHODS}

\section{Reagents}

Human rIL-1 $\beta$, IL-4 and other cytokines were purchased from R\&D systems (Minneapolis, MN). Human rTNF- $\alpha$ and rIFN- $\gamma$ were bought from Roche Applied Science (Indianapolis, IN). ELISA kits for the determination of secreted human CCL-5 (RANTES), CCL-7 (MCP-3), CCL-11 (Eotaxin-1), CCL-24 (Eotaxin-2), and CCL-26 (Eotaxin-3) were obtained from R\&D Systems (Minneapolis, MN). Fetal bovine serum and other cell culture reagents were purchased from Invitrogen (Carlsbad, CA).

\section{Cell Cultures}


Adult human donor eyes (70-85y old), obtained from Eye Banks, were used for the preparation of human retinal pigment epithelial (HRPE) and choroidal fibroblast (HCHF) cells [20, 23, 27]. HRPE and HCHF cells were grown in minimum essential medium supplemented with $10 \%$ fetal bovine serum, non-essential amino acids, penicillin $(100 \mathrm{u} / \mathrm{ml})$, streptomycin $(100 \mathrm{ug} / \mathrm{ml})$ and amphotericin B $(25 \mathrm{ng} / \mathrm{ml})$. All of HRPE cells reacted positively to immune-staining with cytokeratin, cytoskeletal protein marker for epithelial cells. HRPE cell cultures at passages 7 to 10 and HCHF cell cultures at passages 4 to 6 were used in these studies.

\section{Microarray analysis of gene expression in HRPE cells treated with cytokines}

Confluent cultures of HRPE cells grown in $100 \mathrm{~mm}$ dishes (Falcon, Primaria) were treated with inflammatory cytokine mix (IFN- $\gamma(100 \mathrm{u} / \mathrm{ml})$, TNF- $\alpha(10 \mathrm{ng} / \mathrm{ml})$ and $\mathrm{IL}-1 \beta(10 \mathrm{ng} / \mathrm{ml})$ for $8 \mathrm{~h}$ in serum free medium. Purity and integrity of total RNA prepared was verified by absorption spectra and in Agilant 2100 Bioanalyzer. Affymetrix GeneChip arrays (HG U133 plus 2.0) were used for global gene expression profiling. All procedures were performed according to the detailed protocol provided by Affymetrix (Santa Clara, CA) and as described earlier for HRPE [26]. Affymetrix GeneChip Operating Software (GCOS) and GeneSpring software (Silicon Genetics /Agilant, CA) were used for normalizing the gene expression analysis and for comparison between control and treated samples.

\section{Effect of inflammatory cytokines on CCL-5, CCL-7, CCL-11, CCL-24 and CCL-26 secretion by HRPE and HCHF cells}

HRPE and HCHF cultures were grown to confluence in 24 well culture plates in 10\% FBS containing media. To avoid the effects and interactions of various growth factors, cytokines and other proteins present in the serum, all treatments were performed in serum free medium. The cultures were washed once with serum-free medium (SFM) and left in SFM for 5-6 h. Then media were removed and SFM containing various concentrations and combinations of inflammatory cytokines IFN- $\gamma$, TNF- $\alpha$ and IL- $1 \beta$ or inflammatory cytokine mix (ICM) were added to the wells $(1 \mathrm{ml} /$ well $)$. Cultures were incubated for $24 \mathrm{~h}$ and culture supernatant fluids collected were frozen at $-70^{\circ} \mathrm{C}$.
Effect of other cytokines and growth factors on CCL-11, -24 and -26 secretion by HRPE and HCHF cells

Since the individual inflammatory cytokines or ICM did not induce the production of eotaxins (CCL-11, -24 and 26) by HRPE and HCHF cells, we examined the effects of a number of other cytokines and growth factors. HRPE and HCHF cells grown to confluence in 24 well plates were treated with a number of cytokines such as interleukin (IL) -2, -4, -5, -6, -8, -10, -11, -12, -13, and 18 , and growth factors TGF- $\alpha$, bFGF, PDGF, EGF- 1 and TGF- $\beta$. Since IL-4 induced the secretion of CCL-11 and CCL-26, we studied the effect of ICM on IL-4 induced CCL-11 and CCL-26 secretion. CCL-24 secretion was not observed under any of these conditions.

Table 1. Expression of chemokine genes by human retinal pigment epithelial cells (HRPE).

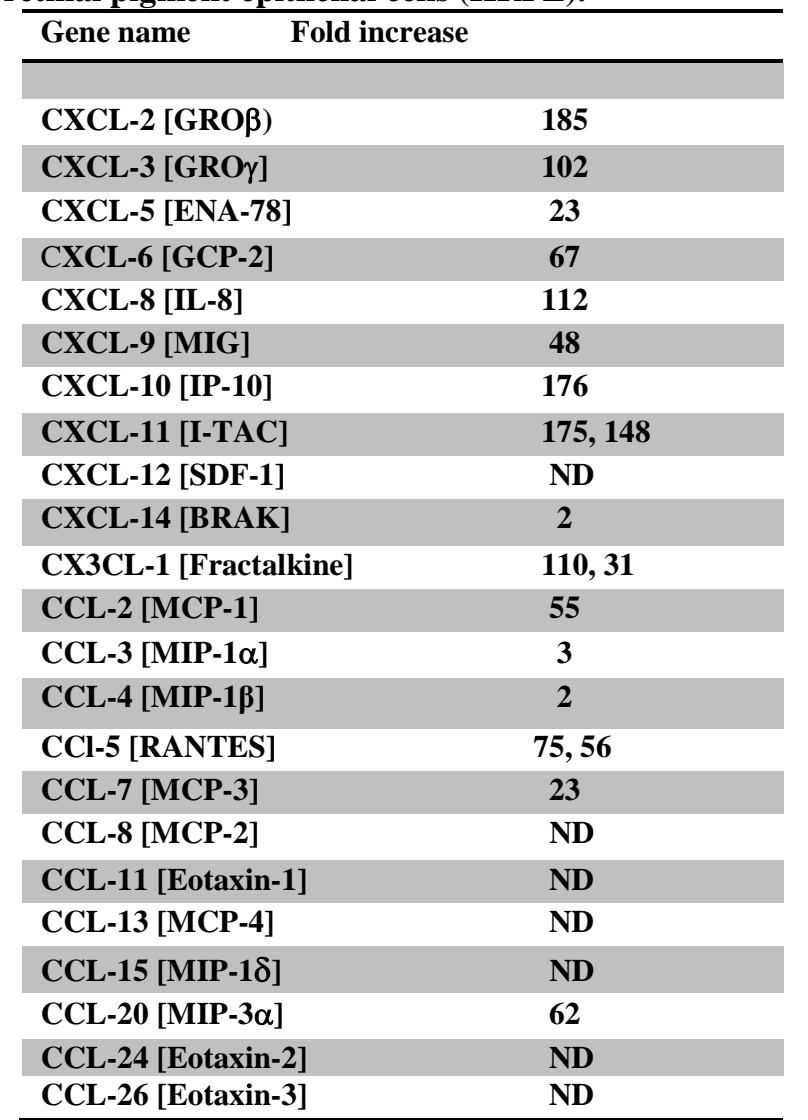

HRPE cells were treated with inflammatory cytokine (IFN- $\gamma$, TNF- $\alpha$ and IL-1 $\beta$ ) mix for $8 \mathrm{~h}$ in serum free medium as described in the methods section. Total RNA prepared from control and treated cells were used for microarray analysis using Affymetrix GeneChip. Results are expressed as fold increase in inflammatory cytokine mix treated HRPE cells compared to control HRPE cells. ND = not detected. 
A

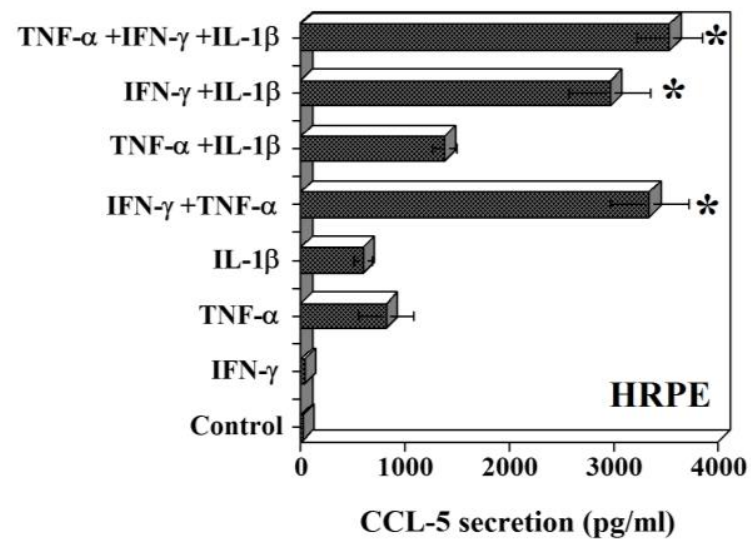

$\mathrm{C}$

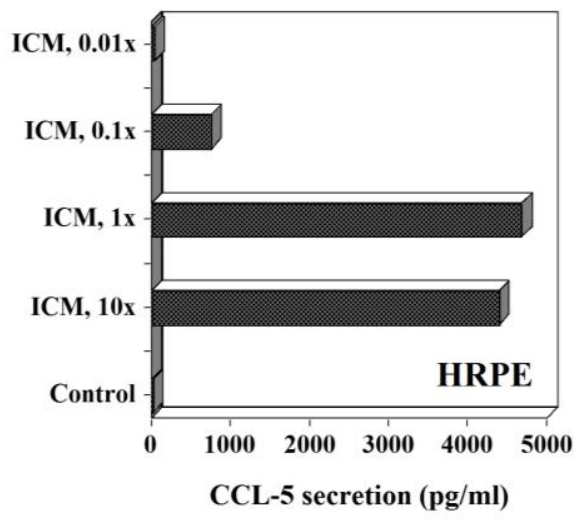

B

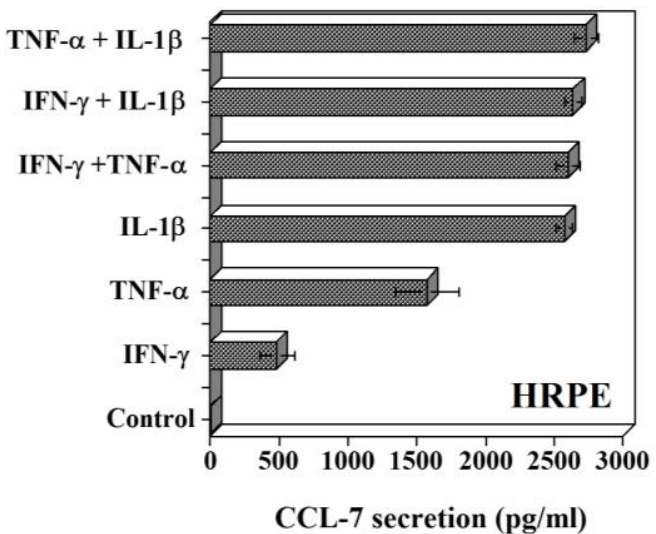

$\mathrm{D}$

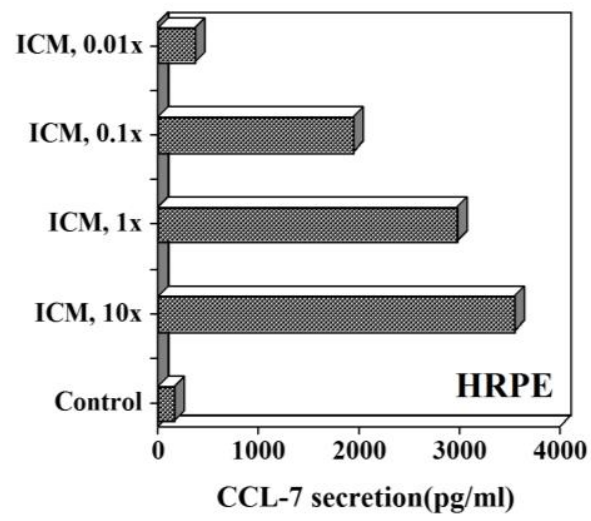

Figure 1. Effect of inflammatory cytokines on CCL-5 (RANTES) and CCL-7 (MCP-3) secretion by human retinal pigment epithelial (HRPE) cells. (A and B) HRPE cells grown to confluence in $24 \mathrm{well}(1 \mathrm{ml} / \mathrm{well}$ ) plates were treated with IFN- $\gamma(100 \mathrm{u} / \mathrm{ml})$, TNF- $\alpha(10 \mathrm{ng} / \mathrm{ml})$ or IL-1 $\beta(10 \mathrm{ng} / \mathrm{ml})$ and various combinations of these cytokines for $24 \mathrm{~h}$ in serum free medium (SFM). (C and D) HRPE cells were treated with various concentrations of inflammatory cytokine mix (ICM, 10x to 0.01x) for $24 \mathrm{~h}$ in SFM. ICM 10x is IFN- $\gamma(100 \mathrm{u} / \mathrm{ml})$, TNF- $\alpha(10 \mathrm{ng} / \mathrm{ml})$ or IL-1 $\beta(10 \mathrm{ng} / \mathrm{ml})$. Levels of CCL-5 and CCL-7 in the culture supernatants were determined by ELISA as described in the methods section. Results are means \pm of 4-5 independent experiments each with duplicate samples. ${ }^{*}$ p values $<0.001$ compared to IFN- $\gamma$ alone.

Effect of IL-4 on inflammatory cytokine induced CCL5, CCL-7, CCL-11and CCL-26 secretion by HRPE and HCHF cells

Next, we sought to examine the effect of ICM in the presence of IL-4. Cultures were incubated with $10 \mathrm{ng} / \mathrm{ml}$ of IL-4 and IFN- $\gamma(100 \mathrm{u} / \mathrm{ml})$, TNF- $\alpha(10 \mathrm{ng} / \mathrm{ml})$ or IL-1 $\beta$ $(10 \mathrm{ng} / \mathrm{ml})$ for $24 \mathrm{~h}$ in serum free medium. Culture supernatants collected were used for the analysis of CCL-
5 and CCL-7 by Elisa.

ELISA Detection of CCL-5, CCL-7, CCL-11, CCL-24 and $C C L-26$

Levels of secreted CCL-5 (RANTES), CCL-7 (MCP-3), CCL-11 (Eotaxin-1), CCL-24 (Eotaxin-2), and CCL-26 (Eotaxin-3) present in the supernatant fluids were determined by specific immunoassays using 
commercially available kits (R\&D Systems, Minneapolis, $\mathrm{MN})$. The experiments were performed according to the manufacturer's instructions. The minimum detectable concentrations for CCL-5, -7, -11, -24, and -26 were 2.0, $1.0,5.0,2.5$ and $2.3 \mathrm{pg} / \mathrm{ml}$ respectively (R\&D Systems, Minneapolis, MN). The lowest standards for CCL-5, CCL-7, CCL-11, CCL-24 and CCL-26 were 31.2, 15.6, $15.6,78.0$ and $7.8 \mathrm{pg} / \mathrm{ml}$ respectively. Chemokine values below the suggested lowest standard-were not used for the calculation of results.

\section{Statistical analysis}

Comparisons were made among the various treatment groups belonging to the same batch of cells grown under similar conditions. Statistical analysis of secreted chemokines by HRPE and HCHF cells treated with various agents were performed by Students " $\mathrm{T}$ " test. "P" values less than 0.05 were considered as significant.

\section{RESULTS}

Microarray analysis of gene expression by HRPE treated with inflammatory cytokines

We used the Affymetrix GeneChip human genome U133 plus 2.0 to evaluate the global gene expression profiles in HRPE cells that were treated with inflammatory cytokine mix (ICM) containing IFN- $\gamma$, TNF- $\alpha$ and IL- $1 \beta$. About 1400 genes were up or down regulated by more than 2 fold (data not shown). The gene expression profile of chemokines presented as fold changes are shown in Table.1. CCR -3 ligands CCL-5 and CCL-7 were upregulated by 75 and 23 fold respectively. However, the expression of other CCR-3 ligands CCL-8, -13, -15 and eotaxins (CCL-11, -24 and -26) was not observed under these conditions. To validate these results, we conducted detailed experiments to study secretion of CCR-3 chemokine ligand proteins.
A

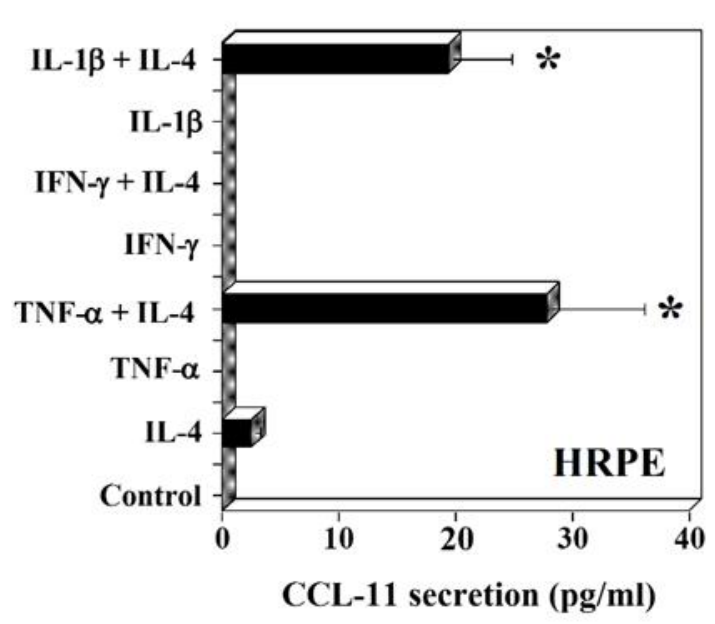

$\mathrm{B}$

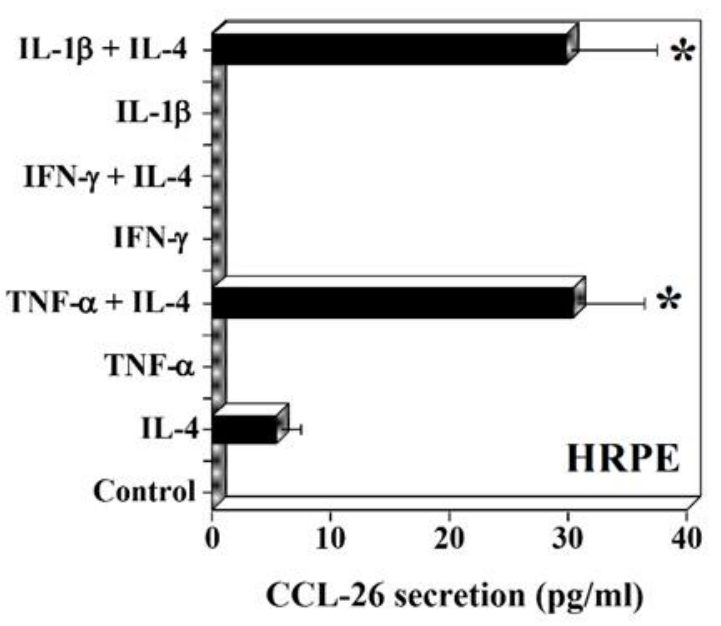

Figure 2. Effect of interleukin-4 (IL-4) and inflammatory cytokines on CCL-11 (eotaxin-1) and CCL-26 (eotaxin-3) secretion by HRPE cells. HRPE cells grown to confluence in 24 well $(1 \mathrm{ml} / \mathrm{well})$ plates were treated with IL-4 (10 ng/ml), TNF- $\alpha(10 \mathrm{ng} / \mathrm{ml})$, IFN- $\gamma(100 \mathrm{U} / \mathrm{ml}), \mathrm{IL}-1 \beta(10 \mathrm{ng} / \mathrm{ml})$ or various combinations of these cytokines for 24h in SFM. Levels of CCL-11 (A) and CCL-26 (B) in culture supernatants were determined by ELISA. Results are means \pm of 4 independent experiments each with duplicate samples. * $P$ values $<0.001$ compared to IL-4 alone. 


\section{Inflammatory cytokines induce CCL-5 and CCL-7 secretion by HRPE cells}

All experiments were performed in serum free medium to avoid the interference of cytokines, growth factors and other constituents present in fetal bovine serum. HRPE cells did not secrete CCL-5 (RANTES) and CCL-7 (MCP-3) constitutively. IFN- $\gamma$ did not influence CCL-5 secretion, but significantly enhanced TNF- $\alpha$ and IL- $1 \beta$ induced CCL-5 secretion (Fig. 1A). On the other hand, IL$1 \beta$ is the most potent inducer of CCL-7 secretion. TNF- $\alpha$ is the second most potent inducer and IFN- $\gamma$ is the least potent inducer of CCL-7 (Fig.1B). The addition of TNF$\alpha$ or IFN- $\gamma$ to IL- $1 \beta$ had no significant effect on CCL-7 secretion. In these studies, we used IFN- $\gamma(100 \mathrm{u} / \mathrm{ml})$, TNF- $\alpha(10 \mathrm{ng} / \mathrm{ml})$ and IL-1 $\beta(10 \mathrm{ng} / \mathrm{ml})$ concentrations (ICM 10x). Then, we sought to evaluate the effects of ICM at lower concentrations (ICM, 1x; ICM, 0.1x and ICM, $0.01 \mathrm{x})$ to simulate the conditions under various pathological conditions. At ICM $0.1 x$, there was a significant secretion of CCL-5 and CCL-7 by HRPE cells compared to untreated cells (Fig.1C, D). These data demonstrate that low concentrations of inflammatory cytokines can stimulate HRPE cells to produce CCL-5 and CCL-7.

\section{Inflammatory cytokines do not induce CCL-11, CCL-24 and CCL-26 (eotaxins) secretion by HRPE}

Constitutive secretion of eotaxins by HRPE cells was not observed. Inflammatory cytokines (ICM) did not induce secretion of CCL-11, -24 and -26 by HRPE (data not shown). A number of cytokines such as interleukin (IL) $2,-5,-6,-8,-10,-11,-12,-13$, and -18 , and growth factors TGF- $\alpha$, bFGF, PDGF, EGF-1 and TGF- $\beta$ ( all at 10 $\mathrm{ng} / \mathrm{ml}$ ) had no detectable effects on eotaxin secretion by HRPE cells (data not shown). Therefore, we sought to examine whether any of the known mediators induce eotaxins in HRPE and HCHF.
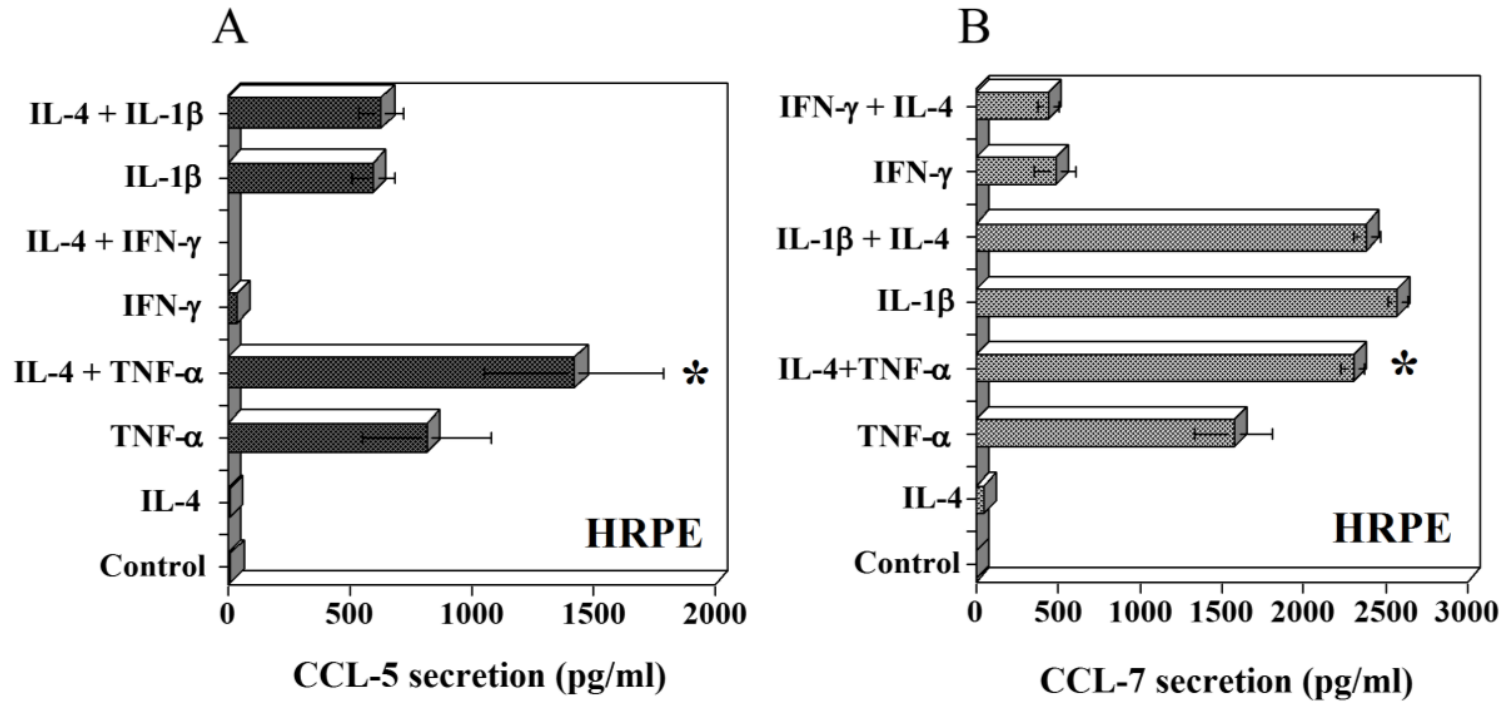

Figure 3. Effect of IL-4 and inflammatory cytokines on CCL-5 and CCL-7 secretion by HRPE cells. HRPE cells grown to confluence in 24 well $(1 \mathrm{ml} / \mathrm{well})$ plates were treated with IL-4 $(10 \mathrm{ng} / \mathrm{ml})$, TNF- $\alpha(10 \mathrm{ng} / \mathrm{ml})$, IFN- $\gamma$ $(100 \mathrm{U} / \mathrm{ml}), \mathrm{IL}-1 \beta(10 \mathrm{ng} / \mathrm{ml})$ or various combinations of these cytokines for $24 \mathrm{~h}$ in SFM. Levels of CCL-5 (A) and CCL-7 (B) in culture supernatants were determined by ELISA. Results are means \pm of 4 independent experiments each with duplicate samples. $* P$ values $<0.001$ compared to TNF- $\alpha$ alone. 


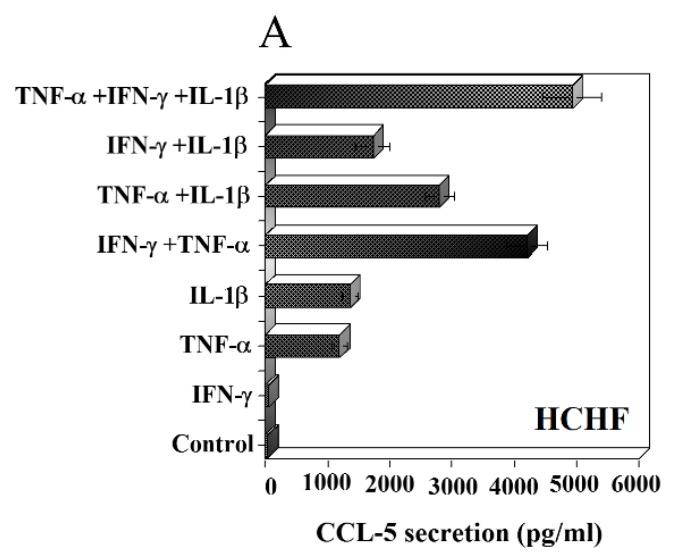

$\mathrm{C}$

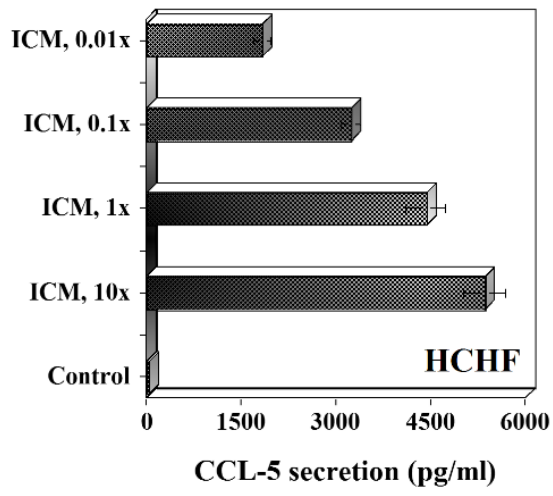

$\mathrm{B}$

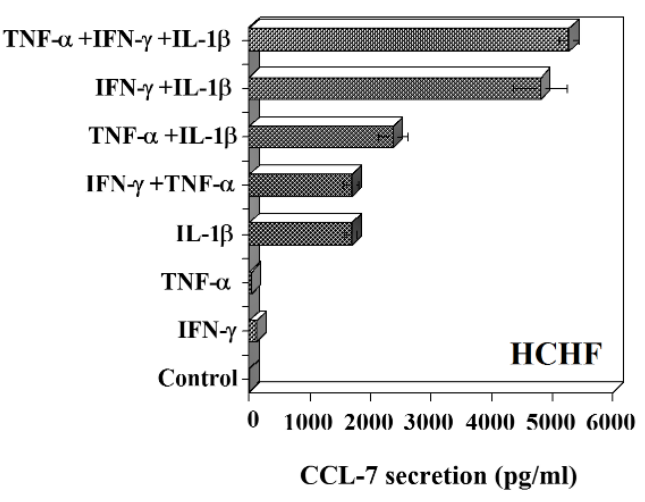

$\mathrm{D}$

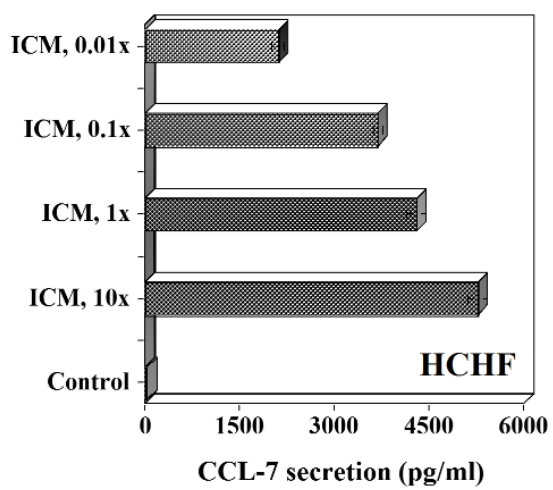

Figure 4. Effect of inflammatory cytokines on CCL-5 (RANTES) and CCL-7 (MCP-3) secretion by human choroidal fibroblast (HCHF) cells. (A and B) HCHF cells grown to confluence in 24 well (1 ml/well) plates were treated with IFN- $\gamma(100 \mathrm{u} / \mathrm{ml})$, TNF- $\alpha(10 \mathrm{ng} / \mathrm{ml})$ or IL- $1 \beta(10 \mathrm{ng} / \mathrm{ml})$ and various combinations of these cytokines for $24 \mathrm{~h}$ in serum free medium (SFM). (C and D) HCHF cells were treated with various concentrations of inflammatory cytokine mix (ICM, 10x to 0.01x) for $24 \mathrm{~h}$ in SFM. ICM 10x is IFN- $\gamma$ (100 $\mathrm{u} / \mathrm{ml}), \mathrm{TNF}-\alpha(10 \mathrm{ng} / \mathrm{ml})$ or IL-1 $\beta$ (10 ng/ml). Levels of CCL-5 and CCL-7 in the culture supernatants were determined by ELISA as described in the methods section. Results are means \pm of 4-5 independent experiments each with duplicate samples.

\section{IL-4 induces CCL-11 and CCL-26, but not CCL-24 expression by HRPE}

IL-4 is known to induce CCL-11 expression by a number of cell types; eosinophils, mast cells, airway epithelial cells, etc [40, 41]. Eotaxins (CCL-11, -24 and -26) were not produced constitutively by HRPE cells. These chemokines were not produced at a concentration of 1 $\mathrm{ng} / \mathrm{ml}$ of IL-4(data not shown). In the presence of IL-4 (10 $\mathrm{ng} / \mathrm{ml})$, HRPE cells produced small quantities of CCL-11 and -26 (Fig. 2A \&B). TNF- $\alpha$ and IL-1 $\beta$, but not IFN- $\gamma$, enhanced IL-4 induced CCL-11 and CCL-26 in HRPE (Fig. 2A \& B). The secretion of CCL-24 (eotaxin-2) was not detected under any of the above conditions (data not shown).

\section{IL-4 enhances TNF- $\alpha$ induced CCL-5 and CCL-7 secretion by HRPE cells}

Next, we examined whether IL-4 had any additional effects on CCL-5 and CCL-7 secretion when exposed to TNF- $\alpha$, IL- $1 \beta$ or IFN- $\gamma$. IL-4 did not induce CCL-5 and 
CCL-7 secretion by HRPE cells. Treatment of cells with TNF- $\alpha$ induced large quantities of both CCL- 5 and CCL7 (Fig. 3A, B). The combination of IL-4 with TNF- $\alpha$ significantly enhanced CCL-5 and CCL-7 secretion. However, IL-4 had no effect on IFN- $\gamma$ and IL-1 $\beta$ stimulated CCL-5 and CCL-7 secretion (Fig. 3A, B).

\section{Inflammatory cytokines induce CCL-5 and CCL-7 secretion by HCHF cells}

Choroidal tissue is the primary site to initiate neovascularization from choriocapillaris in $\mathrm{CNV}$ in $\mathrm{AMD}$ $[4,8,17,33]$. CCL-5 and CCL-7 were not secreted constitutively by HCHF. TNF- $\alpha$ or IL- $1 \beta$ induced the secretion of CCL-5 and this was substantially enhanced when TNF- $\alpha$ and IFN- $\gamma$ were present together (Fig. 4A). CCL-7 secretion was induced by IL- $1 \beta$ and this was substantially enhanced in the presence of IFN- $\gamma$ (Fig. 4B). We also evaluated the dose responses to ICM at lower concentrations $(1 \mathrm{x}, 0.1 \mathrm{x}$ and $0.01 \mathrm{x})$. Even at low concentrations of ICM $(0.01 \mathrm{x})$, there was a significant secretion of CCL-5 and CCL-7 (Fig. 4C, D). These results show that HCHF cells are more sensitive to stimulation with ICM than HRPE cells.

\section{IL-4 induces secretion of CCL-11 and CCL-26 but not CCL-24 by HCHF cells}

When exposed to $10 \mathrm{ng} / \mathrm{ml}$ of IL-4, HCHF induced both CCL-11 and CCL-26 (Fig. 5A, B). These chemokines were not produced at a concentration of $1 \mathrm{ng} / \mathrm{ml}$ of IL4(data not shown). HCHF produced higher levels of CCL11 and CCL-26 compared to HRPE. The synergistic effects of TNF- $\alpha$ and IL- $1 \beta$ were observed on IL-4 induced secretion of CCL-11 by HCHF cells (Fig.5A). In the case of CCL-26, TNF- $\alpha$ and IL- $1 \beta$ slightly enhanced IL-4 induced secretion that was not statistically significant (Fig.5B). IFN- $\gamma$ had no effect on CCL-11 and CCL-26 secretion by HCHF cells (data not shown). The secretion of CCL-24 was not detected under any of these conditions by HCHF cells.
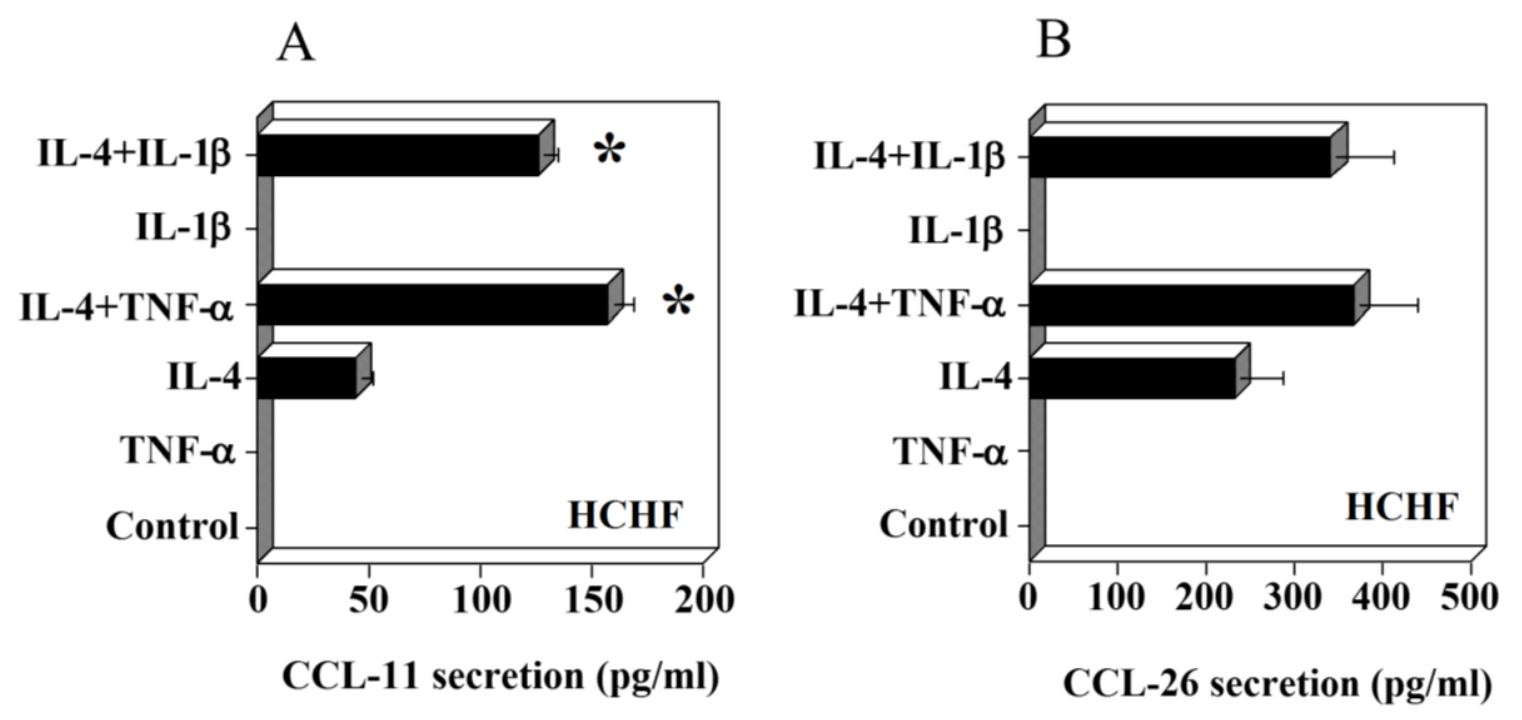

Figure 5. Effect of IL-4 and inflammatory cytokines on CCL-11 (eotaxin-1) and CCL-26 (eotaxin-3) secretion by HCHF cells. HCHF cells grown to confluence in 24 well $(1 \mathrm{ml} / \mathrm{well})$ plates were treated with IL-4 (10 ng/ml), TNF- $\alpha$ $(10 \mathrm{ng} / \mathrm{ml}), \mathrm{IFN}-\gamma(100 \mathrm{U} / \mathrm{ml}), \mathrm{IL}-1 \beta(10 \mathrm{ng} / \mathrm{ml})$ or various combinations of these cytokines for $24 \mathrm{~h}$ in SFM. Levels of CCL-11 (A) and CCL-26 (B) in culture supernatants were determined by ELISA. Results are means \pm of 4 independent experiments each with duplicate samples. * $P$ values $<0.001$ compared to IL-4 alone. 


\section{DISCUSSION}

In this report, we used HRPE and HCHF cells to evaluate the expression of major CCR3 ligands. Both cell types secrete CCL-5 and CCL-7 in the presence of low concentrations of inflammatory cytokines, however, CCL-11, CCL-24 and CCL-26 are not produced either constitutively or in the presence of inflammatory cytokines. Small quantities of CCL-11 and CCL-26, but not CCL-24, are produced only in the presence of high concentrations of IL-4, an anti-inflammatory cytokine that has not been reported to be expressed in the retina. Thus, our in vitro results demonstrate that CCL-5 and CC7 are produced by retinal pigment epithelium and choroidal stromal cells. These ligands may interact with CCR3 in vivo to enhance neovascularization in CNV in AMD.

CCR3 expressed on eosinophils, basophils, mast cells and lymphocytes plays a critical role in the allergic reactions in skin, lungs and other tissues [36-39, 42]. CCR3 is also expressed on microglial, dendritic and airway epithelial and endothelial cells [31, 32, 43]. CCR3 is known to be highly promiscuous and can bind to a number of CC ligands with varying affinities $[31,32,38$, 44]. CCL-11, 24 and 26 are the ligands with specific and potent binding affinities only for CCR3 while CCL-5 and CCL-7 can also bind to CCR1, CCR2, and CCR5 in addition to CCR3 [31, 32, 38, 44]. CCR3 with its ligands CCL11 and CCL24 has been reported to play an essential role in eosinophil recruitment to the lungs and gut mucosa [32, 40, 42].

The role of CCR3 in developmental or pathological angiogenesis has received very little attention $[33,35,45$, 46]. Expression of CCR 3 in retinal and choroidal tissues has not been reported in normal healthy conditions. In our previous study, we demonstrated that HRPE cells expressed CCR 1 but not CCR3 or other CC receptors. [22]. Using immune-histochemical staining, Takeda et al [33] demonstrated the presence of CCR3 proteins on endothelial cells of choroidal blood vessels obtained from AMD patients but not in age-matched control specimens. In these AMD patients, the presence of CCR3 ligands, CCL-11, CCL-24 and CCL-26, was also demonstrated by immunostaining in choroidal tissue stroma primarily consisting of fibroblasts [33]. Expression of CCL-11, CCL-24 and CCL-26 mRNA in human RPE cells was shown by RT-PCR, but the secretion of these eotaxins by HRPE was not demonstrated [33]. Microarray analysis of global gene expression profile of HRPE cells treated with inflammatory cytokine mix did not detect mRNA expression of any of the eotaxins (Table 1). We performed additional secretion studies to validate these results. The secretion of eotaxins by HRPE and HCHF cells was not detected constitutively or in the presence of inflammatory cytokines (Fig. 2, 5). IL-4, only at high concentrations $(10 \mathrm{ng} / \mathrm{ml})$ but not at low concentrations (1 $\mathrm{ng} / \mathrm{ml}$ ), induced secretion of CCL-11 and CCL-26.

The promiscuity of CCR3 reactivity to various ligands suggests potential involvement of ligands other than eotaxins in CNV in AMD $[32,44]$. The expression of CCL-5 and CCL-7, major ligands with binding affinities for CCR3 have not been examined in CNV and retinal pigment epithelium tissues in AMD patient specimens [33, 35, 46]. Microarray studies with HRPE cells showed several fold increases in CCL-5 and CCL-7 mRNA upon treatment with inflammatory cytokine mix (Table 1). Both HRPE and HCHF cells produced significant quantities of CCL-5 and CCL-7 proteins in the presence of low concentrations of inflammatory cytokines (Fig $1 \& 4$ ). The secretion of CCL-5 and CCL-7 was also observed in RPE cells prepared from human fetal and adult donor eyes $[22,25,47]$. Therefore, it is likely that CCL-5 and CCL-7 produced under inflammatory conditions could act as ligands for CCR3 in pathological angiogenesis in CNV. The binding affinities of CCL-5 and CCL-7 to CCR3 are comparable to eotaxins in endothelial cells present in some tissues [43, 48]. The affinities of choroidal endothelial cell CCR3 to its various ligands are not known. Since the secretion of CCL-5 and CCL-7 by HRPE and HCHF cells is greater than a hundred fold under inflammatory conditions, CCL-5 and CCL-7 may be ligands associated with CCR3 mediated CNV in AMD [33, 35, 46]. Recent study has shown increased expression of CCR3 in retina and RPE/choroid tissues of aged (91 years) human donor eyes compared to young (25 years) human donor eyes [49]. Thus enhanced CCR3 expression in retinal and choroid tissue in aged human eyes may be accessible to interaction with CCL5 and CCL7 chemokines produced during inflammatory conditions.

CCL-5 and CCL-7 ligands can interact effectively with other chemokine receptors such as CCR1, CCR2 and CCR5 [31, 32]. CCL-5 and CCL-7 may play role in pathophysiological angiogenic processes by enhancing the homing of endothelial progenitor cells and by influencing expression of angiogenesis associated genes [50-55]. CCR-1 and CCR-5 are expressed both on several hematopoietic and non-hematopoietic cells [31, 32]. In addition, CCR-1 and CCR-5, reported to be expressed on endothelial, epithelial and smooth muscle cells, play roles in neovascularization and wound healing [32, 48, 51, 53]. Inflammatory cytokines TNF- $\alpha$ and IFN- $\gamma$ are known to upregulate CCR2 and CCR5 on endothelial cells and macrophages $[43,48]$. However, the expression of CCR1, CCR2 and CCR5 on choroidal endothelial cells in normal or in AMD patients is unknown [33, 49]. It is possible that CCL-5 and CCL-7 ligands may be associated with 
CCR3 and other CCR receptors in CNV processes in AMD.

Inflammatory reactions are widely thought to be one of the initiating and /or promoting factors in CNV in AMD [56-59]. Recent studies on the role of chemokines and their receptors in CNV in AMD [60- 62] indicate potential new avenues for exploration of chemokine targeting in search of AMD therapies. We demonstrate in this report that cytokines associated with chronic inflammation trigger CCL-5 and CCL-7 release by HRPE and HCHF. The interactions of these ligands with CCR3 may participate in the pathologic processes in AMD.

\section{Acknowledgements}

This research was supported by intramural research program of the National Eye Institute, National Institutes of Health.

\section{References}

[1] Friedman DS, O'Colmain BJ, Munoz B, Tomany SC, McCarty C, de Jong PT, Nemesure B, Mitchell P, Kempen J (2004). Prevalence of age-related macular degeneration in the United States. Arch Ophthal, 122:564-572.

[2] Cruess AF, Zlateva G, Xu X, Soubrane G, Pauleikhoff D et al. (2008). Economic burden of bilateral neovascular age-related macular degeneration: multi-country observational study. Pharmacoeconomics 26:57-73.

[3] Klein R, Chou CF, Klein BE, Zhang X, Meuer SM, Saaddine JB (2011). Prevalence of age-related macular degeneration in the US population. Arch. Ophthalmol, 129: 75-80.

[4] Young RW (1987). Pathophysiology of age-related macular degeneration. Sur Ophthal, 31:291-306.

[5] Das A, McGuire PG (2003). Retinal and choroidal angiogenesis: pathophysiology and strategies for inhibition. Prog Ret Eye Res, 22:721-748.

[6] Zarbin MA (2004). Current concepts in the pathogenesis of age-related macular degeneration. Arch Ophthal, 122:598-614.

[7] Swaroop A, Chew EY, Rickman CB, Abecasis GR (2009). Unraveling a multifactorial late-onset disease: From genetic susceptibility to disease mechanisms for age-related macular degeneration. Annu Rev Genomics Human Genet, 10:19-43.

[8] Ambati J, Fowler BJ (2012). Mechanisms of age-related macular degeneration. Neuron, 75: 26-39.

[9] Bressler NM, Silva JC, Bressler SB, Fine SL, Green W (1994). Clinicopathologic correlation of drusen and retinal pigment epithelial abnormalities in age-related macular degeneration. Retina, 14:130-142.

[10] Grossniklaus HE, Miskala PH, Green WR, Bressler SB, Hawkins BS et al. (2005). Histopathologic and ultrastructural features of surgically excised subfoveal choroidal neovascular lesions: submacular surgery trials report no. 7. Arch Ophthalmol 123:914-921.

[11] Grossniklaus HE, Ling JX, Wallace TM, Dithmar S, Lawson DH, Cohen C, Elner VM, Elner SG, Sternberg $\mathrm{P}, \mathrm{Jr}$ (2002). Macrophage and retinal pigment epithelium expression of angiogenic cytokines in choroidal neovascularization. Mol Vis, 8:119-126.

[12] Hageman GS, Luthert PJ, Victor Chong NH, Johnson LV, Anderson DH, Mullins RF (2001). An integrated hypothesis that considers drusen as biomarkers of immune-mediated processes at the RPE-Bruch's membrane interface in aging and age-related macular degeneration. Prog Ret Eye Res 20:705-732.

[13] Penfold PL, Madigan MC, Gillies MC, Provis JM (2001). Immunological and aetiological aspects of macular degeneration. Prog Ret Eye Res, 20:385-414.

[14] Anderson DH, Mullins RF, Hageman GS, Johnson LV (2002). A role for local inflammation in the formation of drusen in the aging eye. Am J Ophthal, 13:411-431.

[15] Donoso LA, Kim D, Frost A, Callahan A, Hageman G (2006). The role of inflammation in the pathogenesis of age-related macular degeneration. Surv Ophthal, 51:137152.

[16] Nussenblatt RB, Ferris F, 3rd (2007). Age-related macular degeneration and the immune response: implications for therapy. Am J Ophthal, 144:618-626.

[17] Bhutto I, Lutty G (2012). Understanding age-related macular degeneration (AMD) Relationships between the photoreceptor/retinal pigment epithelium/Bruch's membrane/choriocapillaris complex. Mol. Aspec Med, 33:295-317.

[18] Marmor MF and Wolfensberger TJ (1998). The retinal pigment epithelium, function and disease. New York: Oxoford University Press.

[19] Strauss O (2005). The retinal pigment epithelium in visual function. Physiol Rev, 85:845-881.

[20] Nagineni CN, Detrick B, Hooks JJ (1994). Synergistic effects of gamma interferon on inflammatory mediators that induce interleukin- 6 gene expression and secretion by human retinal pigment epithelial cells. Clin Diag Lab Immunol, 1: 569-577.

[21] Nagineni CN, Samuel W, Nagineni S, Pardhasaradhi K, Wiggert B, Detrick B, Hooks JJ (2003). Transforming growth factor-beta induces expression of vascular endothelial growth factor in human retinal pigment epithelial cells: involvement of mitogen-activated protein kinases. J Cell Physiol, 197:453-462.

[22] Momma Y, Nagineni CN, Chin MS, Srinivasan K, Detrick B, Hooks JJ (2003). Differential expression of chemokines by human retinal pigment epithelial cells infected with cytomegalovirus. Invest Ophthalmol Vis Sci 44:2026-2033.

[23] Nagineni CN, Kutty V, Detrick B, Hooks JJ (2005). Expression of PDGF and their receptors in human retinal pigment epithelial cells and fibroblasts: Regulation by TGF-beta. J Cell Physiol, 203: 35-43.

[24] Nagineni CN, Cherukuri KS, Kutty V, Detrick B, Hooks JJ (2007). Interferon-gamma differentially regulates TGF-beta1 and TGF-beta 2 expression in human retinal pigment epithelial cells through JAK-STAT pathway. J Cell Physiol, 210:192-200. 
[25] Shi G, Maminishkis A, Banzon T, Jalickee S, Li R et al. (2008). Control of chemokine gradients by the retinal pigment epithelium. Invest Ophthalmol Vis Sci 49:46204630.

[26] Hooks JJ, Nagineni CN, Hooper LC, Hayashi K, Detrick B (2008). IFN-beta provides immuno-protection in the retina by inhibiting ICAM-1 and CXCL9 in retinal pigment epithelial cells. J Immunol, 180:3789-3796.

[27] Nagineni CN, Kommineni VK, William A, Detrick B, Hooks JJ (2012). Regulation of VEGF expression in human retinal cells by cytokines: Implications for the role of inflammation in age-related macular degeneration. J Cell Physiol, 227:116-126.

[28] Nagineni CN, Raju R, Nagineni KK, Kommineni VK, Cherukuri A, Kutty RK, Hooks JJ, Detrick B (2014). Resveratrol suppresses expression of VEGF by human retinal pigment epithelial cells: Potential nutraceutical for age-related macular degeneration. Aging \& disease 5: 88-100.

[29] Luster AD (1998). Chemokines: Chemotactic cytokines that mediate inflammation. N Engl J Med 338: 436-445.

[30] Murphy PM, Baggiolini M, Charo IF, Hebert CA, Horuk $\mathrm{R}$ et al. (2000). International union of pharmacology. XXII. Nomenclature for chemokine receptors. Pharmacol Rev 52:145-176.

[31] Zlotnik A, Yoshie O (2012). The chemokine superfamily revisited. Immunity 36: 705-716.

[32] Bachelerie F, Ben-Baruch A, Burkhardt AM, Combadiere C, Farber JM et al. (2014). International union of pharmacology. LXXXIX. Update on the extended family of chemokine receptors and introducing a new nomenclature for atypical chemokine receptors. Pharmacol Rev 66:1-79.

[33] Takeda A, Baffi JZ, Kleinman ME, Cho WG, Nozaki M et al. (2009). CCR3 is a target for age-related macular degeneration diagnosis and therapy. Nature 460:225230.

[34] Mason AB, Hoh J (2009). CCR3: Shedding new light on a dark problem? J Mol Cell Biol 1:17-19.

[35] Li Y, Huang D, Xia X, Wang Z, Luo L, Wen R (2011). CCR3 and choroidal neovascularization. PLoS One 6(2):e17106.

[36] Combadiere C, Ahuja SK, Murphy PM (1995). Cloning and functional expression of a human eosinophil CC chemokine receptor. J Biol Chem 270:16491-16494.

[37] Daugherty BL, Siciliano SJ, DeMartino JA, Malkowitz L, Sirotina A, Springer MS (1996). Cloning, expression, and characterization of the human eosinophil eotaxin receptor. J Exp Med 183:2349-2354.

[38] Heath H, Qin S, Rao P, Wu L, LaRosa G et al. (1997). Chemokine receptor usage by human eosinophils. The importance of CCR3 demonstrated using an antagonistic monoclonal antibody. J Clin Invest 99:178-184.

[39] Ponath PD, Qin S, Post TW, Wang J, Wu L et al. (199). Molecular cloning and characterization of a human eotaxin receptor expressed selectively on eosinophils. J Exp Med 183:2437-2448.

[40] Nakamura H, Luster AD, Tateno H, Jedrzkiewicz S, Tamura $\mathrm{G}$ et al. (2001) Il-4 differentially regulates eotaxin and MCP-4 in lung epithelium and circulating mononuclear cells. Am J Physiol lung Cell Mol Physiol 281: L1288-1302.

[41] Odaka M, Matsukura S, Kuga H, Kokubu F, Kasama T et al. (2007). Differential regulation of chemokine expression by Th1 and Th2 cytokines and mechanisms of eotaxin/CCL-11 expression in human airway smooth muscle cells. Int Arch Allergy Immunol 143 Suppl 1:8488.

[42] Humbles AA, Lu B, Friend DS, Okinaga S, Lora J et al (2002). The murine CCR3 receptor regulates both the role of eosinophils and mast cells in allergen-induced airway inflammation and hyperresponsiveness. Proc Nat Acad Sci 99: 1479-1484.

[43] Berger O, Gan X, Gujuluva C, Burns AR, Sulur G et al. (1999). CXC and CC chemokine receptors on coronary and brain endothelia. Mol Med 5:795-805.

[44] Lilly CM, Daugherty BL (2001). A novel LPS-inducible CCR3 activator. Why so many CCR3 ligands? Am J Respir Cell Mol Biol 25: 673-675.

[45] Salcedo R, Young HA, Ponce ML, Ward JM, Kleinman HK et al. (2001). Eotaxin (CCL11) induces in vivo angiogenic responses by human CCR3+ endothelial cells. J Immunol 166:7571-7578.

[46] Mizutani T, Ashikari M, Tokoro M, Nozaki M, Ogura Y (2013). Suppression of laser-induced choroidal neovascularization by a CCR3 antagonist. Invest Opthalnol Vis Sci. 54:1564-1572.

[47] Crane IJ, Kuppner MC, McKillop-Smith S, Knott RM, Forrester JV (1998). Cytokine regulation of RANTES production by human retinal pigment epithelial cells. Cell Immunol 98:s230-237.

[48] Speyer CL, Ward PA ( ). Role of endothelial chemokines and their receptors during inflammation. J Invest Surg 24:18-27.

[49] Wang H, Wittchen ES, Jiang Y, Ambati B, Grossniklaus HE, Hartnett ME (2011). Upregulation of CCR3 by agerelated stresses promotes choroidal endothelial cell migration via VEGF-dependent and -independent signaling. Invest Ophthalmol Vis Sci. 52:8271-8277.

[50] Westerweel PE, Rabelink TJ, Rookmaaker MB, Grone HJ, Verhaar MC (2008). RANTES is required for ischaemia-induced angiogenesis, which may hamper RANTES-targeted anti-atherosclerotic therapy. Thromb Haemost 99:794-795.

[51] Ambati BK, Anand A, Joussen AM, Kuziel WA, Adamis AP, Ambati J (2003). Sustained inhibition of corneal neovascularization by genetic ablation of CCR5. Invest Ophthalmol Vis Sci 44:590-593.

[52] Suffee N, Richard B, Hlawaty H, Oudar O, Charnaux N, Sutton A (2011). Angiogenic properties of the chemokine RANTES/CCL5. Biochem. Soc. Trans 39:1649-1653.

[53] Ishida Y, Kimura A, Kuninaka Y, Inui M, Matsushima $\mathrm{K}$ et al. (2012). Pivotal role of the CCL5/CCR5 interaction for recruitment of endothelial progenitor cells in mouse wound healing. J Clin Invest 122:711-721.

[54] Eyman D, Damodarasamy, Plymate SR, Reed MJ (2009). CCL5 secreted by senescent aged fibroblasts induces proliferation of prostate epithelial cells and expression of genes that modulates angiogenesis. J 
Cellular Physiol 220:376-381.

[55] Bousquenaud M, Schwartz C, Leonard F, RollandTurner M, Wagner D, Devaux Y (2012). Monocyte chemotactic protein 3 is a homing factor for circulating angiogenic cells. Cardiovascular Res 94:519-525.

[56] Bird AC (2010). Therapeutic targets in age-related macular disease. J Clin Invest 120:3033-3041.

[57] Hagstrom SA, Ying GS, Pauer GJ, Sturgill-Short GM, Huang J, Callanan DG, Kim IK, Klein ML, Maguire MG, Martin DF; Comparison of AMD Treatments Trials Research Group. (2013). Pharmacogenetics for genes associated with age-related macular degeneration in the Comparison of AMD Treatments Trials (CATT). Ophthalmology 120: 593-599.

[58] Wang Y, Wang VM, Chan CC (2011). The role of antiinflammatory agents in age-related macular degeneration (AMD) treatment. Eye (Lond) 25: 127-139.

[59] Nussenblatt RB, Byrnes G, Sen HN, Yeh S, Faia L, Meyerle C, Wroblewski K, Li Z, Liu B, Chew E, Sherry
PR, Friedman P, Gill F, Ferris F 3rd. et al. (2010). A randomized pilot study of systemic immunosuppression in the treatment of age-related macular degeneration with choroidal neovascularization. Retina 30: 1579-1587.

[60] Shi X, Semkova I, Müther PS, Dell S, Kociok N, Joussen AM (2006). Inhibition of TNF-alpha reduces laser-induced choroidal neovascularization. Exp Eye Res 83:1325-1334.

[61] Olson JL, Courtney RJ, Mandava N (2007). Intravitreal infliximab and choroidal neovascularization in an animal model. Arch Ophthalmol 125: 1221-1224.

[62] Xie P, Kamei M, Suzuki M, Matsumura N, Nishida K, Sakimoto S, Sakaguchi H, Nishida K (2011). Suppression and regression of choroidal neovascularization in mice by a novel CCR2 antagonist, INCB3344. PLOS ONE 6, e28933. 